November 2016

\title{
The Charm of Secrecy: Secrecy and Society as Secrecy Studies
}

Susan Maret

San Jose State University

Follow this and additional works at: https://scholarworks.sjsu.edu/secrecyandsociety

Part of the Business Commons, History Commons, Law Commons, Life Sciences Commons, Political Science Commons, and the Public Affairs, Public Policy and Public Administration Commons

\section{Recommended Citation}

Maret, Susan. 2016. "The Charm of Secrecy: Secrecy and Society as Secrecy Studies." Secrecy and Society 1(1). https://doi.org/10.31979/2377-6188.2016.010101

https://scholarworks.sjsu.edu/secrecyandsociety/vol1/iss1/1

This Article is brought to you for free and open access by the School of Information at SJSU ScholarWorks. It has been accepted for inclusion in Secrecy and Society by an authorized administrator of SJSU ScholarWorks. For more information, please contact scholarworks@sjsu.edu.

\section{(c) (1)}

This work is licensed under a Creative Commons Attribution 4.0 License. 


\section{The Charm of Secrecy: Secrecy and Society as Secrecy Studies}

Keywords

secrecy, Secrecy Studies, Georg Simmel, social problems, wicked problems 


\section{The Charm of Secrecy: Secrecy and Society as Secrecy Studies Susan Maret}

Sandra Braman $(2011,1)$ writes that "historically, new scholarly journals appeared when new subjects of study achieved disciplinary or subdisciplinary status. Today, they are also created when new audiences and communities of scholarly practice appear." It is important to note that new scholarly publications also appear when seemingly intractable social problems reach a level of such significance they demand a central avenue of inquiry. Such is the case with the study of secrecy. In creating the peerreviewed open access journal Secrecy and Society, which exclusively focuses on secrecy and associated conditions of information, the exploration of all things secrecy now has a scholarly home.

In my discussion below, I frame secrecy as a compelling social problem that often reflects Horst W.J. Rittel and Melvin M. Webber's (1973) idea of a wicked problem. In addition to this framework, I suggest the field of Secrecy Studies offers another way of investigating secrecy across the social landscape. I conclude my discussion by introducing contributions to this inaugural issue of Secrecy and Society by several of its editorial board members.

\section{Secrecy as a Compelling Social (and Wicked) Problem}


Certain subjects and/or challenges, which start as a whisper, may take decades to gain foothold in academic and public consciousness and formally "claimed" as a social problem. ${ }^{1}$ Since the conclusion of World War II, secrecy, for example, as the intentional or unintentional concealment of information (Simmel 1950, 330), has been the subject of distinct government investigations, scholarly inquiry, and consistently reported in the mainstream and alternative media. While these explorations have shaped some understanding of how individuals, groups, and institutions hold secrets that "can be either an action or knowledge...can be potential or effective, stable or unstable, factual or imaginary" (Bellman 1981, 1), secrecy has not been uniformly characterized as a social problem.

But what is a social problem and how does secrecy qualify as one? Joel Best $(2001,8)$ identifies a "social problem claim" as an argument having four elements:

(a) that some condition exists; (b) that it is problematic (i.e., that it is troubling and ought to be addressed); (c) that it has particular characteristics (e.g., that it is common, has known causes or serious consequences, or is a problem of a particular type); and (d) that some sort of action should be taken to deal with it.

Applying Best's four criteria as outlined above, secrecy and its various forms and uses indeed constitutes a social problem, and a compelling one at that. But here I go further in suggesting that secrecy may also constitute a wicked problem. That is, social problems that fall into the "wicked" framework are 
"akin to that of 'malignant' (in contrast to 'benign') or 'vicious' (like a circle) or 'tricky' (like a leprechaun) or 'aggressive' (like a lion, in contrast to the docility of a lamb)" (Rittel and Webber 1973, 160). Wicked problems are inherently complex, have no fixed or obvious resolution, and are often "a symptom of another problem"; moreover, wicked problems "defy efforts to delineate their boundaries and to identify their causes, and thus to expose their problematic nature" (Rittel and Webber 1973, 165, 167).

For example, secrecy as wicked problem may manifest as "purposive hiding and masking" (Simmel 1950, 330), which holds the potential to cloak misdeeds and crimes. This variant of secrecy reflects Simmel's $(1906,463)$ observation that secret-keeping can be "the sociological expression of moral badness... obstinacy and cynicism may often enough stand in the way of disguising the badness." For example, the secrecy that accompanies certain veillances ${ }^{2}$ intrudes on the boundaries of privacy, reputation, and carry with it violations of personhood. Secrecy wedded to spying, for example, moderates an individual's awareness of what information certain corporations (Bamberger and Mulligan 2015; Herbert 2016; Lubbers 2015; Shorrock 2008), contractors (Permanent Subcommittee on Investigations 2012; Regan and Monahan 2014; Shorrock 2007), and government agencies collect, use in profiling, share, and disseminate (Boghosian 2013; Greenberg 2012; Greenwald, Poitras, and MacAskill 2013; Lubbers 2012; Marx 1988; Weiner 2013). In these cases, secrecy leverages access to 
Secrecy and Society, Vol. 1, No. 1 [2016], Art. 1

information/knowledge, therefore qualifying as a "tampering of communications" (Friedrich 1972). ${ }^{3}$ One such example of this strain of secrecy is the Federal Bureau of Investigation's (FBI) proposed rule to restrict an individual's right under the Privacy Act of 1974 to obtain information about themselves as utilized in the Bureau's Next Generation Identification (NGI) system (Federal Register 2016). The NGI database is comprised of fingerprint, palm prints, iris scans, and facial recognition (biometric) data. While the existence of the NGI database is public, access to records is restricted to certain bodies within the criminal justice intelligence system. The FBI describes NGI as providing "the criminal justice community with the world's largest and most efficient electronic repository of biometric and criminal history information" (Federal Bureau of Investigation n.d.); 24,510 local, state, tribal, federal, and "international partners" submitted queries to NGI in September 2016 (Federal Bureau of Investigation 2016).

In November 2016, the Electronic Privacy Information Center (EPIC) sued the FBI to obtain a secret memoranda of understanding (MOU) between the Bureau and U.S. Department of Defense (DoD) on biometric data transfers. This particular exercise in information sharing between FBI and DoD raises concerns not only pertaining to "data integrity," that is, accuracy and error rates (U.S. General Accounting Office 2016), but safeguarding personally identifiable information (PII) and its unauthorized use domestically and in foreign intelligence. More to the point, the Bureau's 
rulemaking - and MOU - appears to fly in the face of the Fair Information

Practices that state:

There must be a way for a person to find out what information about the person is in a record and how it is used;

There must be a way for a person to prevent information about the person that was obtained for one purpose from being used or made available for other purposes without the person's consent;

There must be a way for a person to correct or amend a record of identifiable information about the person;

Any organization creating, maintaining, using, or disseminating records of identifiable personal data must assure the reliability of the data for their intended use and must take precautions to prevent misuses of the data. (Department of Health, Education, and Welfare, Secretary's Advisory Committee on Automated Personal Data Systems 1973)

\section{Other Wicked Problems}

Certain aspects of the secret society may also constitute a wicked problem. As described by Simmel $(1906,483)$, the secret society "itself characterized by its secret." Secret societies as "secret islands" (Hourcle 1993) that spring to mind here range from intelligence and defense agencies to corporations who competitively guard trade secrets and inventions. This stealth world carries the stolen promise of full transparency, carefully worded responses, hidden destinations, heroics, history, and technologies.

In addition, certain uses of secrecy are not entirely reflective of Georg Simmel's $(1906,448)$ reciprocal knowledge, or the "positive condition of social relationships." That is, secrecy is enabled through certain legal (rational) provisions such as trade agreements and confidential business information, as well as government policies and programs (e.g., closed 
material procedures, deliberative process privilege, security classification of information and markings) (Maret 2014). We may go as far to note that the struggle to maintain security and address risk (and vulnerabilities) especially in the arena of terrorism prevention and state actions - are essentially tied to secrecy. The struggle for security, which range from controlled conditions of Panoptical spying to finding needles in a haystack of big data, to algorithmic optimism, are fostered by the "saturation of time and space by speed, making daily life the last theater of operations, the ultimate scene of strategic foresight" (Virilio 1990, 92).

The study of uneven (asymmetric) information flows that occur through a variety of channels such as social media, the mainstream and alternative media have made the formal study of secrecy and its close cousins (censorship, confidentiality, conspiracy-making, deception, ignorance, lying, privacy, propaganda, spying, silence, thought control ${ }^{4}$, and veillance) imperative in coming to terms with (post)modern life, where the "distinction between risk and cultural perception of risk is becoming blurred" (Beck 2009, 11).

\section{Secrecy Studies as a Foundation for Secrecy and Society}

To study secrets is to enter a land where "what human beings want above all to protect (sic, is) the sacred, intimate, the fragile, the dangerous, and the forbidden" (Bok [1983], 1989: 281). The central focus of Secrecy 
and Society then is to investigate, problematize, and report on types of concealment and the cluster of associated information conditions that make secrecy the unique social - and often wicked - problem it is. Simply, Secrecy Studies as I intend it here "accounts for the way secrets are practiced both officially and in everyday life" (Bellman 1981, 21). Secrecy Studies is a placeholder, a launching point, a foundation for the investigation of secrecy across the very fabric of society, that according to one theorist,

is built on secrecy, from "front" organisations which draw an impenetrable screen over the concentrated wealth of their members, to the "official secrets" which allow the state a vast field of operation free from any legal constraint; from the often frightening secrets of shoddy production hidden by advertising, to the projections of an extrapolated future, in which domination alone reads off the likely progress of things whose existence it denies, calculating the responses it will mysteriously make. (Debord 1998, 52)

Secrecy Studies recognizes that disciplinary boundaries have "proved inadequate to take up interdisciplinary, multidisciplinary, or transdisciplinary work" (Maret 2011, xvi) regarding the problem of secrecy. ${ }^{5}$ As a journal of Secrecy Studies, the work plan of Secrecy and Society responds to "the sheer extent of all we do not know about the many aspects of secrecy, and the need for careful comparative and interdisciplinary studies devoted to them" (Bok [1983], 1989, 282).

When I wrote a few years ago of a way to organize the study of secrecy through Secrecy Studies (Maret 2011), it was my hope the field would take root in several ways: first, through the "traditional" disciplines in 
Secrecy and Society, Vol. 1, No. 1 [2016], Art. 1

applying existing theory and research methods at hand, and two, in actively creating novel visions and tools to expand understanding of secrecy and its charm across intellectual landscapes, genres, and faultlines. As I suggested, Secrecy Studies requires the

development of bold speculative theory and reinvigoration of qualitative research methods would serve Secrecy Studies in illuminating relationships, construct alternative histories, acknowledge everyday stories and experiences, deconstruct semiotical regimes, and expose subtle dynamics, which among other matters, give rise to ruptures of information and communication such as asymmetry, conspiracy theories, disinformation, propaganda, and the leak. (Maret 2011, xvii)

Simmel's $(1906,465)$ "charm of secrecy" is the key to the evolution of Secrecy Studies, whether the investigation concerns culturally-produced artifacts (e.g, film, genre television, fiction, myths) or fresh research into secrecy and communication in the natural world. This persistent charm ${ }^{6}$, or allure, encompasses the many realms of secrecy, including the investigation of forms and practices across disciplinary, cultural, and geographic boundaries. As secrecy is first and foremost connected to shifting knowledge currencies in social relationships ${ }^{7}$, some elusive and far from view, while some are plainly evident and connected to problems of publicity and transparency, charm is an essential element to the study of secrecy. ${ }^{8}$

At this point in the discussion, a return to Simmel's thought is worth reporting as he is one of the most astute scholars on the nature of secrecy in human relationships. Simmel's (1906) influential article "The Sociology of 
Secrecy and of Secret Societies" pinpoints secrecy as fundamentally sociological in terms of its significance concerning information/knowledge and ability to be used in exchange. But in his discussion, Simmel also offers us insight into the power dynamics of those who conceal and those who remain outside "the circle of secrecy":

The application of secrecy as a sociological technique, as a form of commerce without which, in view of our social environment, certain purposes could not be attained, is evident without further discussion. Not so evident are the charms and the values which it possesses over and above its significance as a means, the peculiar attraction of the relation which is mysterious in form, regardless of its accidental content. In the first place, the strongly accentuated exclusion of all not within the circle of secrecy results in a correspondingly accentuated feeling of personal possession. For many natures possession acquires its proper significance, not from the mere fact of having, but besides that there must be the consciousness that others must forego the possession... since exclusion of others from a possession may occur especially in the case of high values, the reverse is psychologically very natural, viz., that what is withheld from the many appears to have a special value. (Simmel 1906: 464)

As an ingredient of charm, possession is then connected to secrecy in terms of control and/or perceptions of ownership over information. Possession takes shape through shifting roles, interests ${ }^{9}$, and values that play out in the sharing and cloaking of information/knowledge. The secret, made possible by possession, resides in the realization that "certain goals are not at all achievable in light of our social surroundings" (Simmel 2009, 326). It is at the birth of the secret, where the possession of some speciallydesignated information/knowledge secures, so to speak, the possibility of a second world alongside of the obvious world, and the latter is most strenuously affected by the 
former. Every relationship between two individuals or two groups will be characterized by the ratio of secrecy that is involved in it. Even when one of the parties does not notice the secret factor, yet the attitude of the concealer, and consequently the whole relationship, will be modified by it. (Simmel 1906, 462)

Thus the charm of secrecy - and Secrecy Studies - suggests a multiplicity of directions in investigating the rhizomatic "secrecy process" that Stanley K. Tefft $(1980,37)$ outlines as the "tensions and/or conflicts between the secret holder (holders) and outsiders that necessitate concealment." Thus the charm of secrecy brings with it possibility in terms of lighting up power relations regarding the concealment of embarrassing disclosures, forbidden acts, illegality, inefficiency, evasion of responsibility, and corruption (Simmel 1950). Moreover, Secrecy Studies is concerned with "controlling processes" that surround particular kinds of information/knowledge. Controlling processes, according to Laura Nader $(1995,712)$, "allows the incorporation of the full panoply of key concepts ideology, hegemony, social and cultural control - in the study of both invisible and visible aspects of power." Here it is critical to state that "power secures knowledge, but knowledge also secures power. Systems of powerknowledge contain both emancipatory and repressive elements" (Jansen $1991,7)$. In this way, secrecy, even Secrecy Studies, are connected to information liberation,

which is the general project of using information to move toward a society free of domination. It doesn't make much sense to say that information itself is oppressed. Rather, information is often a means of domination of both humans and the environment. The goal is to make 
information into a tool for liberation. (Martin 1988, 172-3)

Using Secrecy Studies as a foundation, below I offer a flexible menu of subjects that target secrecy as a social, often wicked problems, and may serve as fodder for the evolution of Secrecy Studies:

- Access to secret archives (Akevot Institute for Israeli-Palestinian Conflict Research 2016);

- Classified communities as secret societies; other constructs such as epistemic communities and small worlds, or "a society in which mutual opinions and concerns are reflected by its members, a world in which language and customs bind its participants to a worldview" (Chatman 1999, 213), hold promise for the advancement of Secrecy Studies;

- Comparative secrecy; specific typologies of concealment from dirty secrets, government secrecy, nuclear secrecy, "open secrets," to state secrets (Maret 2011);

- The complex ecosystem of secrecy, blowback, tradeoffs, and unintended consequences ${ }^{10}$;

- Conditions of information such as censorship, information warfare, privacy, propaganda, surveillance and their intersection with secrecy; the formation and role of conspiracy theories and belief systems also remains unexplored country as it pertains to radicalization and extremism. Central here is power/knowledge, particularly "the 
ensemble of rules according to which the true and the false are separated and specific effects of power are attached to the true" (Foucault [1972], 1980, 132);

- Forbidden knowledge (taboo, occult, sacred, unspeakable) and investigations into things perhaps "we should not know" (Shattuck 1996,1)；

- The influence of secrecy and associated information conditions on civil liberties and human rights in the "cosmopolitan society" (Beck 2002);

- Information ethics and secrecy practices;

- Leaks and "sanctions for disclosure" (Shils 1956); in other words, how does "leaking" of information by government or corporate whistleblowers influence democratic expectations of the right to know, information ethics, and trust?;

- Legal and regulatory basis for secrecy;

- "Neutral" definitions of secrecy (Bok [1983], 1989), including typologies such as positive and negative secrecy (Simmel 1906) and "functional" and "disfunctional" secrecy (Friedrich 1972);

- Quantitative and qualitative studies on the role of secrecy and the nature of harm to individuals and states (e.g., national security);

- Resilience or "governing through failure" (Chandler 2016) and the impact of secrecy, for example, in disasters, terrorism, risk communication and perception. Resilience "constructs risky or 
problematic 'communities' in terms of understanding the complex adaptive processes through which social and environmental interaction constitutes diverse threats to security and well-being at different scalar levels" (Chandler 2013, 287). Resilience also looks at uncertainty, an information condition brought on by selective information disclosure. This is connected with Chatman's $(1999,211)$ concept of "life in the round," with its "enormous degree of imprecision and, surprisingly, accepted levels of uncertainty."

- The role of "subjugated" standpoints, "preferred because they seem to promise more adequate, sustained, objective, transforming accounts of the world" (Haraway 1988, 584). Moreover, subjugated knowledges are concerned "with a knowledge of historical struggles" (Foucault [1972], 1980, 83). Within Secrecy Studies, the acknowledgment of subjugated knowledge(s) can push the theoretical and methodological;

- The role of secrecy in restorative and transitional justice;

- Secrecy as information policy; one example is the use of secrecy by governments that center on national security (Maret 2016);

- Secrecy as portrayed in art, film, and literature;

- Secrecy and its relationship to discourse;

- "Secret science" and controls on science and technology (Felbinger and Reppy 2011; Foerstel 1993; Mumford 1964b);

- Teaching secrecy "literacy" across levels of society as an element of 
citizenship and information rights as human rights ${ }^{11}$;

- The tension of technology and parallel use; for example, certain technologies provide individuals and groups anonymity and privacy (e.g, Tor, PGP) and opportunities to challenge official statements (e.g, citizen monitoring or citizen science that run counter to claims of "acceptable risk"). Certain technologies are also used by governments to spy and entrap (e.g. Tor exploits by NSA). We can frame parallel use by way of technologies of autonomy, or democratic technics that run counter to authoritarian technics (Mumford 1964a), as well as the idea of those technologies of political control, situated "at the intersection of a host of concerns about relations between individuals and the state, the possibility that technology offers for extending and limiting human action and the dilemmas of exercising coercive force in open societies" (Rappert 1999, 749);

- The unintentional constraint of information through various avenues such as poor information design, institutional failures, disasters, and accidents (as in shit happens) ${ }^{12}$;

- Visualization and mapping of trends, uses of secrecy, and the entities that employ secrecy (Clarke 2016; Lombardi 2003).

\section{Secrecy Studies as the Investigation of Insiders and Outsiders}

If we take Simmel at his word that secrecy is connected to what we 
know about one another, and this knowledge is therefore essential to the trust we hold in them, then it is critical we

consider that possession of full knowledge does away with the need of trusting, while complete absence of knowledge makes trust evidently impossible. Whatever quantities of knowing and not knowing must commingle, in order to make possible the detailed practical decision based upon confidence, will be determined by the historic epoch, the ranges of interests, and the individuals. (Simmel 1906, 450)

To chart Simmel's circle of secrecy is to examine shifting sands as it relates to insiders and outsiders and the dangers that "obviously goes far beyond risks to those who keep secrets" (Bok [1983],1989, 26). The inhabitants of secrecy's second, parallel world to the "obvious world" are citizens of ownership and exclusion, those insiders and outsiders that are rulemakers and overseers, the rule-bound and victim. Insiders to secrecy, for example, have a distinct advantage in having the "awareness that others have to do without it" (Simmel 2009, 326), with "it" being data, facts, or information/knowledge deemed worthy of control, possession, and concealment. On the other hand, "the outsider's tension with respect to experienced secrecy generates the desire to to cut it down to size, confine it, preferably dispel it all together" (Bok [1983], 1989, 36).

One striking example of insiders and outsiders is the secrecy that involves the criminal and/or is reflective of a lapse of ethics or administrative evil (Adams and Balfour 2015). As Adams, Balfour, and Reed (2006, 682) carefully distinguish, individuals may participate in "acts of evil" without 
being conscious of their ethical responsibilities; in fact, "ordinary people may simply be acting appropriately in their organizational role." Perhaps the linking of administrative evil with secrecy appears at first glance hyperbolic; however, when we consider the use of torture, used to coerce "enemy combatants" housed at Abu Ghraib, Guantanamo Bay, and various off-thegrid-CIA black sites, devised by licensed psychologists and put into motion by medical personnel and public officials as program and policy, there is no longer a question of exaggeration. Torture as enhanced interrogation, not only illegal under international conventions, is characterized by Veteran Intelligence Professionals for Sanity (2015) as "ineffective, and contrary to all American laws, ideals, and intelligence practices." We may then problematize that "a culture of technical rationality has enabled a new and bewildering form of evil that we call administrative evil" (Adams, Balfour, and Reed 2006,682 ) is at the dark heart of such programs. To extend the ideas of these authors, we might pose that if certain organizational cultures also prize secrecy as a means to protect interests and maintain or enhance security, administrative evil bound to secrecy is then a wicked problem and has a direct relationship with information/knowledge, civil liberties, and human rights.

For example, after the events of September 11 we might look to "security thinking" to analyze how administrative evil takes hold in institutions. Secrecy Studies has an important role to play in identifying 
members of a circle of secrecy and those affected outsiders; moreover, Secrecy Studies has the potential to frame secrecy, which can "fuel gross intolerance and hatred towards outsiders" (Bok [1983], 1989, 28). By way of Simmel's circle, Secrecy Studies makes room for investigating the farranging influence and power of secrecy as a social problem to further understand Weber's impersonal "rational" bureaucracy.

When we consider secrecy across the social landscape, it is more than abstractly philosophical. Secrecy and its relationship with information/knowledge is deeply tied to being, identity, history, and the confidence we have in individuals and organizations. As I see it, Secrecy Studies confronts the hidden which may intrude on autonomy, personhood, and the rule of law; through the critical deliberation of novel theory and methods - intellectual tools - Secrecy Studies has the ability to mark out new territories and dimensions of experience. Such is the charm of secrecy.

\section{Secrecy and Society as a Journal of Secrecy Studies}

This inaugural issue of Secrecy and Society includes multiple visions of secrecy and associated information conditions from the $S \& S$ editorial board. For example, Clare Birchall's essay on Secrecy Studies supplements and expands my views; Gary Marx's "Humpty Dumpty was Wrong - Consistency in Meaning Matters: Some Definitions of Privacy, Publicity, Secrecy and other Family Members" contributes to Secrecy Studies by exploring how we 
Secrecy and Society, Vol. 1, No. 1 [2016], Art. 1

categorize and understand certain informational states such as privacy. Brian Martin's discussion of Sue Curry Jansen's landmark work on censorship and secrecy is a paper presented at the May 17, 2016 symposium at Muhlenberg College honoring Jansen's work; Sue Curry Jansen's "Secrecy, Confidentiality, and 'Dirty Work': The Case of Public Relations" synthesizes ideas from her research on the social problem of "dirty work" performed by governments, corporations, and the public relations industry as secret societies. Chris Hables Gray's "Could Technology End Secrecy?" discusses secrecy as "being shaped by the scientific discoveries and technological creations of today, and by the politics and understandings that contextualize them." Using the Panama Papers leak as a focus, Secrecy and Society editorial board member David S. Levine with colleague Lisa Lynch pose six questions regarding democratic accountability and leaks, in their "Whither Megaleaking? Questions in the Wake of the Panama Papers. ${ }^{13}$ Historian Antoon De Baets, in his article titled "A Historian's View of the International Freedom of Expression Framework," analyzes the relevance and significance of the U.N. human rights framework to historians. De Baets writes that the "framework provides standards to discuss the merits of different law types and offers criteria to evaluate arguments in discussions about free expression, information and secrecy." Rounding out this first issue of Secrecy and Society is a brief comparison of the "companion" documents Liberty and Security in a Changing World (President's Review Group on 
Intelligence and Communications Technologies 2013) and the 2016 United Nations Office of the High Commissioner, Report of the Special Rapporteur on the Right to Privacy, Joseph A. Cannataci. Wrapping up the issue is Brian Martin's review of lawyer-journalist Scott Horton's The Lords of Secrecy: The National Security Elite and America's Stealth Warfare. The "lords of secrecy" are leaders of the national security and intelligence community, who Horton notes "exercise the power to create secrets." Horton's quote on the ability of the powerful to create secrets suggests the enduring charm of secrecy, and is further way to think on secrecy in this premier issue of Secrecy and Society.

\section{References}

Adams, Guy B., and Balfour, Danny L. 2015. Unmasking Administrative Evil. $4^{\text {th }}$ ed. New York: Routledge.

Adams, Guy B., Balfour, Danny L., and Reed, George E. 2006. "Abu Ghraib, administrative evil, and moral inversion: The value of 'Putting Cruelty First'." Public Administration Review 66 no. 5 (2006): 680-693.

Akevot Institute for Israeli-Palestinian Conflict Research. 2016. Point of Access: Barriers for Public Access to Israeli Government Archives. (accessed July 2, 2016) http://akevot.org.il/en/point-of-access/

Applegate, Scott D. 2013. "The Dawn of Kinetic Cyber." In $5^{\text {th }}$ International Conference on Cyber Conflict (CyCon), edited by K. Podins, J. Stinissen, M. Maybaum, 163-177. Tallinn, Estonia: NATO Cooperative Cyber Defence Centre of Excellence and IEEE. (accessed July 14, 2016) https://ccdcoe.org/cycon/2013/proceedings/cyconBOOK2013.pdf 
Bamberger, Kenneth A., and Deirdre K. Mulligan. 2015. Privacy on the Ground: Driving Corporate Behavior in the United States and Europe. MIT Press.

Beck, Ulrich. 2002. "The Cosmopolitan Society and its Enemies." Theory, Culture \& Society 19(1-2): 17-44. Polity Press.

. 2009. World at Risk. Trans. Ciaran Cronin. Cambridge, UK:

Bellman, Beryl L. 1981. "The Paradox of Secrecy." Human Studies 4(1): 124.

Bentham, Jeremy. 1843. The Works of Jeremy Bentham, Vol. 2, Published Under the Superintendence of His Executor John Bowring. London, Simpkin, Marshall.

Best, Joel. 2001. Introduction: The Diffusion of Social Problems. In How Claims Spread: Cross-national Diffusion of Social Problems, edited by Joel Best, 1-18. New York: Walter de Gruyter

Bok, Sissela. [1983], 1989. Secrets: On the Ethics of Concealment and Revelation. New York: Vintage Books.

Boghosian, Heidi. 2013. Spying on Democracy: Government Surveillance, Corporate Power, and Public Resistance. San Francisco: City Lights Publishers.

Braman, Sandra. 2011. "Defining Information Policy." Journal of Information Policy 1: 1-5. (accessed June 8, 2016) http://people.tamu.edu/ Braman/bramanpdfs/38_defininginfopolicy.pdf

Chandler, David. 2016. "How the World Learned to Stop Worrying and Love Failure: Big Data, Resilience and Emergent Causality." Millennium- 
Journal of International Studies 44(3): 391-410.

. 2013. "International Statebuilding and the Ideology of Resilience." Politics 33 (4): 276-286.

Chatman, Elfreda A. 1996. "The Impoverished Life-World of Outsiders." Journal of the American Society for Information Science 47 (3): 193206.

. 1999. "A Theory of Life in the Round." Journal of the Association for Information Science and Technology 50 (3): 207-217.

Clarke, Keir. 2016. The Panama Papers Mapped. Maps Mania, April 6. Accessed July 7, 2016.

https://googlemapsmania.blogspot.com/2016/04/the-panama-papersmapped.html

Cotterrell, Roger. 1999. "Transparency, Mass Media, Ideology and Community," Cultural Research 3 (4): 414-426.

Debord, Guy. Comments on the Society of the Spectacle. Trans. Malcolm Imrie. New York: Verso, 1998.

Department of Health, Education, and Welfare, Secretary's Advisory Committee on Automated Personal Data Systems. 1973. Records, Computers, and the Rights of Citizens. Washington, DC: Government Printing Office. Accessed July 3, 2016.

https://aspe.hhs.gov/report/records-computers-and-rights-citizens

Electronic Privacy Information Center. 2016. EPIC Sues FBI Over Biometric Data Program. November 15. Accessed November 15. https://www.epic.org/news/2016/

Federal Bureau of Investigation. n.d. Next Generation Identification (NGI). 
Accessed November 19, 2016. https://www.fbi.gov/services/cjis/fingerprints-and-other-biometrics/ngi

2016. Next Generation Identification

Monthly Fact Sheet. October. Accessed November 17, 2016. https://www.fbi.gov/file-repository/ngi-monthly-fact-sheet/view

Federal Register. 2016. Privacy Act of 1974; Implementation. May 5, 2016. Accessed July 4, 2016. https://www.federalregister.gov/articles/2016/05/05/201610119/privacy-act-of-1974-implementation

Felbinger, Jonathan, and Reppy, Judith. 2011. "Classifying Knowledge, Creating Secrets: Government Policy for Dual-Use Technology." In Government Secrecy, Research in Social Problems and Public Policy, 19, edited by Susan Maret, 277-299. Bingley, United Kingdom: Emerald Group Publishing Limited.

Foerstel, Herbert N. 1993. Secret Science: Federal Control of American Science and Technology. Westport, CT: Praeger.

Foucault, Michel. [1972], 1980. Power/Knowledge: Selected Interviews \& Other Writings 1972-1977, edited by Colin Gordon, translated by Colin Gordon, Leo Marshall, John Mepham, and Kate Soper. New York: Pantheon.

Friedrich, Carl J. 1972. The Pathology of Politics: Violence, Betrayal, Corruption, Secrecy, and Propaganda. New York: Harper \& Row.

Greenberg, Ivan. 2012. Surveillance in America: Critical Analysis of the FBI, 1920 to the Present. Lanham, MD: Lexington Books.

Greenwald, Glenn, Poitras, Laura, and MacAskill Ewen. 2013. "NSA Shares Raw Intelligence including Americans' Data with Israel." The Guardian September 11. Accessed July 4, 2016. https://www.theguardian.com/world/2013/sep/11/nsa-americans- 
personal-data-israel-documents

Haraway, Donna. 1988. "Situated Knowledges: The Science Question in Feminism and the Privilege of Partial Perspective." Feminist Studies 14(3): 575-599.

Herbert, David Gauvey. 2016. "This Company Has Built a Profile on Every American Adult." Bloomberg Businessweek August 5. Accessed August 5, 2016. https://www.bloomberg.com/news/articles/2016-08-05/thiscompany-has-built-a-profile-on-every-american-adult

Hourcle, Laurent R. 1993. "Military Secrecy and Environmental Compliance." New York University Environmental law Journal 2(2): 316346.

Jansen, Sue Curry. 1991. Censorship: The Knot that Binds Power and Knowledge. New York, Oxford University Press.

Latour, Bruno. 2005. Reassembling the Social: An Introduction to ActorNetwork-Theory. New York: Oxford University Press.

Lombardi, Mark. 2003. Global Networks. New York: Drawing Center.

Lubbers, Eveline. 2012. Secret Manoeuvres in the Dark: Corporate and Police Spying on Activists. New York: Palgrave Macmillan.

. 2015. "Undercover Research: Corporate and Police Spying on Activists. An Introduction to Activist Intelligence as a New Field of Study." Surveillance \& Society 13(3/4): 338-353. Accessed July 3 , 2016. http://ojs.library.queensu.ca/index.php/surveillance-andsociety/article/view/undercover_research

Lukes, Steven. 1974. Power: A Radical View. New York: Macmillan. 
Mann, Steve. 2013. "Veillance and Reciprocal Transparency: Surveillance Versus Sousveillance, AR Glass, Lifeglogging, and Wearable Computing." In IEEE International Symposium on Technology and Society (ISTAS) : Social Implications of Wearable Computing and Augmediated Reality in Everyday Life, 1-12, June 27-29, University of Toronto: IEEE. Accessed July 3, 2016.

http://glogger.eyetap.org/papers/docs/IEEE_ISTAS13_Veillance1_Mann. pdf

Maret, Susan. 2016. "Introduction." In Intelligence and Information Policy for National Security: Key Terms and Concepts, edited by Jan Goldman and Susan Maret. Lanham, MD: Rowman and Littlefield.

. 2014. The Moynihan Commission's Secrecy by Regulation and its Value to Environmental Sociology. Sociological Imagination, 50(2): 105-137.

. 2011. "Introduction: Government Secrecy." In

Government Secrecy, Research in Social Problems and Public Policy, 19, edited by Susan Maret, xi-xxx. Bingley, United Kingdom: Emerald Group Publishing Limited.

. 2009. "Overview and Organization, Government

Secrecy." In Government Secrecy: Classic and Contemporary Readings, edited by Susan Maret and Jan Goldman, xvii-5. Westport, CT: Libraries Unlimited.

Martin, Brian. 1988. Information Liberation: Challenging the Corruptions of Information Power. London: Freedom Press, 1998.

Marx, Gary T. 1988. Undercover: Police Surveillance in America. Berkeley, CA: University of California Press.

Mumford, Lewis. 1964a. "Authoritarian and Democratic Technics." Technology and Culture 5 (1): 1-8. 
Brace, Jovanovich.

1964b. The Pentagon of Power. New York: Harcourt,

Nader, Laura. 1997. "Controlling Processes: Tracing the Dynamic Components of Power." Current Anthropology 38 (5): 711-737.

Permanent Subcommittee on Investigations. 2012. Federal Support for and Involvement in State and Local Fusion Centers. U.S. Senate, Homeland Security and Governmental Affairs, October 3. Accessed July 4, 2016. https://www.hsgac.senate.gov/subcommittees/investigations/media/inv estigative-report-criticizes-counterterrorism-reporting-waste-at-stateand-local-intelligence-fusion-centers

Prados, John, and Jimenez-Bacardi Arturo. 2016. Gerald Ford White House Altered Rockefeller Commission Report in 1975; Removed Section on CIA Assassination Plots. National Security Archive, February 29, Accessed July 1, 2016. http://nsarchive.gwu.edu/NSAEBB/NSAEBB543Ford-White-House- Altered-Rockefeller-Commission-Report/

Rappert, Brian. 1999. "Assessing Technologies of Political Control." Journal of Peace Research 36 (6): 741-750.

Regan, Priscilla M., and Monahan, Torin. 2014. "Fusion Center Accountability and Intergovernmental Information Sharing." Publius: The Journal of Federalism 44(3): 475-498.

Reitinger, Philip. 2011. Testimony, Examining the Cyber Threat to Critical Infrastructure and the American Economy: hearing before the Subcommittee on Cybersecurity, Infrastructure Protection, and Security Technologies of the Committee on Homeland Security, House of Representatives, March 16, first session. (accessed July 15, 2016) https://www.gpo.gov/fdsys/pkg/CHRG-112hhrg72221/pdf/CHRG112hhrg72221.pdf

Rittel, Horst W.J., and Webber, Melvin M. 1973. "Dilemmas in a General 
Theory of Planning." Policy Sciences 4(2): 155-169.

Shattuck, Roger. 1997. Forbidden Knowledge: From Prometheus to Pornography. San Diego, CA: Harcourt Brace \& Company.

Shils, Edward A. 1956. The Torment of Secrecy: The Background and Consequences of American Security Policies. Glencoe, IL: Free Press.

Shorrock, Tim. Domestic Spying, Inc. Corpwatch, November 27. Accessed July 4, 2016. http://www.corpwatch.org/article.php?id=14821

2008. Spies for Hire: The Secret World of Intelligence Outsourcing. New York: Simon and Schuster.

Simmel, Georg. 2009. Sociology: Inquiries into the Construction of Social Forms, 2 vols. Edited and translated by Anthony J. Blasi, Anton K. Jacobs, Mathew Kanjirathinkal. Boston: Brill.

. 1950. The Sociology of Georg Simmel, edited and translated by Kurt H. Wolff. New York: Free Press. . 1906. "The Sociology of Secrecy and of Secret Societies." The American Journal of Sociology 11(4): 441-498.

Stember, Marilyn. 1991. "Advancing the Social Sciences Through the Interdisciplinary Enterprise." The Social Science Journal 28 (1): 1-14.

Swedberg, Richard. 2005. "Can There be a Sociological Concept of Interest?." Theory and Society 34(4), 359-390.

Tefft, Stanley K. 1980. "Secrecy, Disclosure, and Social Theory." In Secrecy, A Crosscultural Perspective, edited by Stanley K. Tefft, 35-74. New York: Human Sciences Press. 
Secretary's Advisory Committee on Automated Personal Data Systems. 1973. Records, Computers, and the Rights of Citizens: Report of the Secretary's Advisory Committee on Automated Personal Data Systems. U.S. Department of Health, Education, and Welfare. Washington DC: Government Printing Office. Accessed August 14, 2016. https://epic.org/privacy/hew1973report/

U.S. General Accounting Office. 2016. Facial Recognition Technology: FBI Should Better Ensure Privacy and Accuracy. August 3. GAO 16-267. Accessed November 17, 2016. http://www.gao.gov/products/GAO-16$\underline{267}$

Veteran Intelligence Professionals for Sanity. 2015. "Veteran Intelligence Professionals Challenge CIA's 'Rebuttal' on Torture." Consortiumnews September 14. Accessed September 29, 2016. https://consortiumnews.com/2015/09/14/us-intel-vets-decry-cias-useof-torture/

Virilio, Paul. 1990. Popular Defense \& Ecological Struggles. New York: Semiotext(e).

Weiner, Tim. 2013. Enemies: A History of the FBI. New York: Random House.

Weisgerber, Marcus. 2016. "Air Force Says It Recovered Trove of Files in Corrupted Database." Defense One, June 15. Accessed June 15, 2016. http://www.defenseone.com/technology/2016/06/air-force-says-itrecovered-trove-files-corrupted-database/129112/?oref=d-river

Zetter, Kim. 2015. Countdown to Zero Day: Stuxnet and the Launch of the World's First Digital Weapon. New York: Broadway Books. 
1 The use of social is by way of Latour $(2005,7)$ as "not as a special domain, a specific realm, or a particular sort of thing, but only as a very peculiar movement of re-association and reassembling."

2 Mann $(2013,1)$ suggests that veillance is "a broad concept that includes both surveillance (oversight) and sousveillance (undersight), as well as dataveillance, uberveillance, etc."

3 In this discussion, I choose to avoid complex definitional discussions of the differences between information and knowledge. As used in this discussion, knowledge is information communicated. Information gives form to knowledge - and communication.

4 Lukes $(1974,23)$ states "thought control takes many less total and more mundane forms, through the control of information, through the mass media, and through the process of socialisation."

5 Marilyn Stember (1991) differentiates these three disciplinarities with multidisciplinarity involving "several disciplines who each provide a different perspective on a problem or issue," interdisciplinarity is "integration of the contributions of several disciplines to a problem or issue is required," and transdisciplinarity is "concerned with the unity of intellectual frameworks beyond the disciplinary perspectives."

6 In several translations of Simmel, fascination (with secrecy) is also used.

7 Adapted from Foucault ([1972], 1980).

8 Publicity is described by Jeremy Bentham $(1843,19)$ as "exposure - the completest exposure of the whole system of procedure-whatever is done by anybody, being done before the eyes of the universal public." Transparency on the other hand, is a "process operating differently in different contexts" (Cotterrell 1999: 416), but also "a process of requiring persons in relations of community with others to account for their actions, understandings and commitments as regards matters directly relevant to those relations" (Cotterrell 1999, 414).

9 See Swedberg (2005).

10 A recent case is that of the Stuxnet worm, developed by the U.S. and Israel and released to Iranian infrastructure in 2010. Stuxnet infected "120,000 Microsoft Windows systems worldwide, however, it is only known to have damaged systems in the Fuel Enrichment Plant in Natanz, Iran. This has led to popular speculation that the Stuxnet worm was designed to specifically target this facility" (Applegate 2013, 171). See Alex Gibney's 2016 film Zero Days, Zetter (2015), and testimony of Philip Reitinger (2011) to the House Committee on Homeland Security, Subcommittee on Cybersecurity, Infrastructure Protection, and Security Technologies Committee. These accounts suggest that Department of Homeland Security and Congress were perhaps unaware of Stuxnet's origins as "kinetic cyber," or cyberweapon (Applegate 2013) and the potential "blow back" to U.S. and worldwide critical infrastructure.

11 Since 2006, I've taught one of the only secrecy and freedom of information courses in U.S. higher ed, offered at the School of Information, San Jose State University. In this course, we investigate theory, history, policies, and cases related to types of secrecy, censorship, and aspects of freedom of information.

12 Such as the U.S. Air Force June 2016 disclosure that its Air Force Inspector General (IG) Automated Case Tracking System (ACTS) files were not only corrupted but the Air Force contractor Lockheed "lost" the data. So far, 100,000 IG investigations dating back to 2004 have been recovered (Weisgerber 2016); also see various works by sociologist William R. Freudenburg on institutional failures.

13 The unauthorized disclosure of security-related information. 